Article

\title{
A New Service Class in the Public Sector? The Role of Femonationalism in Unemployment Policies
}

\author{
Paula Mulinari \\ Department of Social Work, Institution of Health and Society, 20506 Malmö, Sweden; E-Mail: paula.mulinari@mah.se
}

Submitted: 14 May 2018 | Accepted 6 August 2018 | Published: 22 November 2018

\begin{abstract}
This article aims to explore the content embedded in the figuration of 'foreign-born unemployed women' and how discourses of gender equality are used to create an emerging racialised service class within the Swedish public sector. Influenced by the concept of femonationalism, the article explores how the introduction of the Extra Services unemployment reforms facilitates the creation of a service class whose purpose is to make it possible for the regular workforce to continue to function despite cutbacks and the neoliberal management of professional care work in the public sector. The study identifies a shift in the discourse, where, while migrant women continue to be represented as victims in public discourses concerning unemployment, they are also represented as being lazy and unwilling to work, qualities that legitimate the need for more repressive interventions towards the group, often described as feminist interventions that will rescue migrant women and their children.
\end{abstract}

\section{Keywords}

femonationalim; gender equality; labour market; migrant women; unemployment; Sweden

\section{Issue}

This article is part of the issue "Gender Equality and Beyond: At the Crossroads of Neoliberalism, Anti-Gender Movements, 'European' Values, and Normative Reiterations in the Nordic Model”, edited by Lena Martinsson (University of Gothenburg, Sweden), Diana Mulinari (Lund University, Sweden), and Katarina Giritli Nygren (Mid Sweden University, Sweden).

(C) 2018 by the author; licensee Cogitatio (Lisbon, Portugal). This article is licensed under a Creative Commons Attribution 4.0 International License (CC BY).

\section{Introduction}

In September 2017, the Swedish Government, consisting of the Green Party and the Social Democratic Party, announced an investment of 135 million SKE for measures aimed to 'facilitate for foreign-born women to get access to paid work' (Government Press Release, 2017b). The government also gave central labour market actors, such as the Swedish Agency for Economic and Regional Growth, directives aiming to increase the employment of 'foreign-born women' (Government Press Release, 2018). In the spring budget of 2018, a new investment of 141 million SEK was made, specifically to 'get foreign-born women into the labour market' (Government Press Release, 2017b). The goal to 'establish' (etablera) foreign-born women in the labour market is today a highly prioritised area of concern by the state and central labour markets actors, including municipalities, local governments, and civil organisations. The unem- ployment of migrant women is described as a problem for the women themselves as well as a challenge to gender equality in Sweden. Announcing several new reforms targeting foreign-born women before the Social Democratic Congress in 2017, Prime Minister Stefan Löfven and Minister of Finance Magdalena Andersson wrote:

The employment rate among foreign-born is undoubtedly lower than it has been in a long time, but it still takes too long before migrants who have recently arrived to begin working. In addition, there are major differences between women's and men's employment that are completely unacceptable. This difference is not acceptable in a gender-equal country such as Sweden, where we built our wealth on the idea that everyone who can work works. We Social Democrats want to continue removing the barriers so that women will have the same opportunity to work as men. Our goal is for men and women to 
have the same power and the same opportunities to shape their lives. Therefore, we have abolished the child allowance introduced by the right-wing government. We are looking into parental insurance so that the newly arrived with children can get into a job faster and withdraw the establishment guarantee for all those who do not seek work. Of course, we should have the same requirement for new arrivals as for other job seekers. But we need to do more. Society has not taken this important issue seriously enough. We want to see more possibilities and also more demands. All women and men have the obligation to make themselves employable. We, therefore, propose the following to get more foreign-born women into work. (Andersson \& Löfven, 2017, author's translation)

Among the proposals are investment in education, the validation of former work experience and competencies, as well as investment in Swedish for immigrants (SFI). Central is that the possibilities are regulated though demands. For example, higher demands are placed on women who are home with older children to read SFI and study during their parental leave. If the woman does not participate her "right" to social security is withdrawn.

When the Social Democratic Party, with the support of the Green Party, won the 2014 elections, one of their first decisions was to terminate FAS 3, a reform made by the conservative Reinfeldt government (2006-2014). FAS 3 was strongly criticised by both the Swedish labour unions and unemployment organisations as it neither created jobs nor paths towards work and forced unemployed citizens to work without any financial compensation (Paulsen, 2015). The 2014 government closed FAS 3 and instead created the Extra Services (ES) reform. The main and fundamental difference is that people are paid salaries in parity with collective agreements and that workers can be employed only in the public and nonprofit sectors in jobs where they supposedly do not do regular workers' tasks. The aim of ES is to 'stimulate the employment of people without support that have difficulties in getting employment' (Arbetsförmedlingen, 2018). Extra employees can be employed in the public sector, in fields such as healthcare, school, day-care, elder care or disability care or within state agencies as long as the employment is not within a sector that offers products or services to the market. Today, ES workers can also be employed in nonprofit organisations working with children and youth and registered religious communities. Formally, the categories of people who can access the ES reform are those who are unemployed and are inscribed in the Swedish Public Employment Service or who are newly arrived (Arbetsförmedlingen, 2018). People that are unemployed can have an ES employment for two years. ES was presented as a labour market policy intervention aimed at increasing, among other things, the employment rate of foreign-born women. One of the aims of the reforms presented by Löfven and Andersson is to break the 'isolation of foreign-born women' through the expansion of ES in the public sector.

There need to be easier ways into the labour market, especially for those with little or no education who are older. Therefore, the Extra Services within the public sector needs to be expanded. It both strengthens welfare and functions as a way into the labour market, especially for foreign-born women. (Andersson \& Löfven, 2017, author's translation)

The establishment of foreign-born women in the labour market is often articulated as a measure for promoting gender equality-for the women themselves, but also for the nation. According to gender scholar Sara R. Farris (2017), we need to explore the dialectic relationship between the representations of migrant women and their economic and political role as workers in the current phase of capitalism. Feminist researchers have shown how discourses around gender equality in Sweden are used to legitimise ethnonationalism and increased demands of forced assimilation (Martinsson, Griffin, \& Giritli Nygren, 2016). Inspired by these researchers' contributions, this article aims to explore the representation of the unemployed foreign-born woman and how this hegemonic representation creates a specific type of emerging gendered and racialised labour force, though an analysis of ES.

Theoretically, the article aims to explore the strength of the scholarship that bridges a postcolonial focus on the creation of colonial and racist scripts within the labour market with a Marxist feminist emphasis on political economy and social reproduction (Farris, 2017; Lowe, 2015; Mohanty, 2003). The article is based on a qualitative case study of the unemployment projects taking place in the city of Malmö, Sweden during 2017-2018.

The article is organised as follows. First, a short overview of the field will be provided followed by a presentation of the theoretical and methodological frameworks. The article's central focus lies in the analysis of the ways these labour policies are acted upon at the level of the municipality and in the national political debate. The first identifies how the category of foreign migrant women is constructed in a workshop at the municipality. The second analysis, through selected speeches and documents, explores which ideas are embedded within the figuration of the unemployed foreign-born woman. The third identifies a shift from discourses of victims to be helped to discourses of ungrateful women resisting help. Finally, I will argue how this specific figuration of the foreign-born woman within labour market policy is, in the name of gender equality, used to create a specific service class within the public sector.

\section{Governing the Unemployed: Gendered and Racialised Discourses}

There is an incipient but growing field of research, inspired by intersectional analysis, which explores how mi- 
grant women's labour market participation has been affected by gendered, racialised, and class-based inequalities (de los Reyes, 2014). These studies have identified the position of migrant women in low-paying jobs, such as elder care (Lill, 2007), service work (Abiala, 2000; Mulinari, 2017), informal/formal care work (Gavanas, 2010) and, more recently, in professions like academics and medicine (Behtoui, 2017; Mulinari, 2018; Povrzanović Frykman \& Öberg, 2018). This research shows the specific challenges that migrant women encounter, from a lack of recognition of their skills and qualifications to racist fantasies about migrant families' attitudes towards the participation of migrant women in the labour market (Anthias, Kontos, \& Morokvasic-Müller, 2013). The contribution of this research has been fundamental for many reasons; one of the most important, in my view, is that it identifies the central role of everyday, institutional racism in creating a labour market segregated by class, gender, and race. Another important contribution is that these scholars have challenged the hegemonic representation in Sweden that migrant women do not engage in paid work. Studies have demonstrated not only the multiple and contradictory positions of migrant women in the labour market but also that migrant women have both challenged and made possible the heteronormative, gender-segregated labour market regime shaping Swedish industrial relations through their labour market participation (Ardalan, 2016; Mulinari, 2007).

Another relevant field of research that inspires my work is the scholarly tradition that critically examines how the category of 'migrants' is produced and reproduced within the 'unemployment complex'. In his study of unemployment policies and projects, financed by the European Social Fund (ESF), migration researcher Victor Vesterberg (2015) shows how labour market activities are aimed at ensuring that the participants emerge as employable by transforming them from 'migrants' to 'Swedish'. In a similar study analysing a number of these projects, Vesterberg and Dahlstedt (2018) show how the 'employable citizen' is created as the opposite of the racialised other. Migrant women, the authors assert, are represented as victims of their own cultures and traditions, and their unemployment is understood as being the consequence of these factors. The notion that 'cultural difference' explains unemployment among migrant women is, according to migration researcher Jenni K Larsson, the hegemonic explanation used by professionals within the Swedish Public Employment Service (arbetsförmedlningen) on both a national and local level (Larsson, 2015). Cultural geographer Malin McGlinn further develops these arguments and asserts that at the core of the logic of the ESF there is the need to create unemployed people so that Swedish/white professionals can be employed in different projects aiming to activate the unemployed (McGlinn, 2018). An important result and a central contribution of these studies is that they show that, despite the extensive evidence of ethnic discrimination and racism in the labour market, the profession- als engaged in the expansive field of labour integration projects targeting mostly racialised populations continue to explain migrant women's unemployment in terms of their cultural background. Furthermore, these studies show that the representation of migrant women seems to be rather constant.

Another important contribution of these studies is that they identify the merger of social and labour policy. Researchers have explored the configuration of crime control and migration control, conceptualised as 'crimmigration' (Barker, 2017), which is leading to the increasing criminalisation of migrants. Parallel to this, and to some extent embedded within one another, it is possible to clearly distinguish an increasing merge between social policy and labour policy, with higher demands towards racialised citizens participating in labour and language activities in order to obtain social assistance (Dahlstedt \& Lalander, 2018; Gubrium \& Fernandes, 2014). While it is the Swedish Public Employment Service that is responsible for implementing the government unemployment policies, the municipality is becoming a central actor within the unemployment area as municipalities are responsible for the unemployed that are dependent on social assistance (Vikman \& Westerberg, 2017). The merge between social policy and labour policy is hence often implemented through the local municipalities as these are responsible for social assistance. There are still few studies that explore the experiences of unemployed migrant women themselves within the unemployment complex. One of the few is gender scholars Katarina Gritili Nygren and Ulrika Schmauch's study of how newly arrived migrant women experience the 'integrationist' space of SFI. The authors show that, despite the ethnonationalist agenda as well as its repressive frame, the SFI environment is transformed by the migrant women themselves into an inclusive place of friendship and safety (Gritili Nygren \& Schmauch, 2012, p. 610).

Swedish scholarship exploring the racial and gendered aspects of the unemployment complex is often theoretically inspired by debates on governability. This research has been crucial in challenging ethnonationalist assumptions at the core of both public debates and social policies. In the following pages, I will, inspired by their contribution, shift the focus from an analysis of classification systems based on race, nationhood, and ethnicity, and their impact in the labour market, towards an analysis of how these classifications systems regulate social policies regarding the creation of a gendered and racialised labour force, inspired by the concept of 'femonationalism'.

\subsection{Theoretical Framework: From Governance to Labour Power}

Sara R. Farris (2017) uses the concept of femonationalism to grasp the convergence between rather distinct political figures and political projects in their representation of Muslim and non-Western migrant women as vic- 
tims in need of rescue. According to Farris, the discourse of femonationalism operates not only in right-wing xenophobic rhetoric but also within neoliberal workfare programmes and feminist-inspired integration programmes. Farris's originality lies in her ability to link racist representations of Muslim women as victims to an analysis of the role of migrant women in European labour markets. According to the author, femonationalism has a central role in the commodification of the racialised labour force into the spheres of social reproductive work, such as childcare, elder care, and cleaning.

Farris (2017) argues that migrant women constitute a specific fraction of the labour supply, a regular army of reproductive labour. According to Farris, gender scholars have made central contributions in analysing the colonial discourses embedded in the figuration of the foreignborn woman; however, she argues, there has been less research on the following question:

Is there something specific to women, particularly to non-Western women, and more precisely, something specific to their political-economic role in the current conjuncture? (Farris, 2017, p. 188)

Farris challenges us to explore not only the representation of migrant women but also the political-economic function of this figuration. According to Farris, migrant female labour plays a crucial role in the restructuring of welfare regimes both by providing care and reproductive labour and by giving women-conceptualised as belonging to the nation-the possibility of being genderequal. Farris argues that migrant women have their own scripted labour market: while on one hand it follows the rules of the existing gender and sexual contracts, on the other hand, it also follows the rules of what she conceptualises as a 'racial contract', 'according to which ethnic minorities and people of colour perform the least desirable and valued tasks in a society' (Farris, 2017, p. 194).

The author provides relevant insights by bridging poststructuralist studies of racism with the field of political economy, convincingly showing that femonationalism functions to guarantee the supply of female migrant labour, which plays a central role in the restructuring of European welfare regimes. Farris's analysis is based on the situations in France, Italy, and the Netherlands, countries that differ from Sweden in the ways through which social reproduction entangles labour markets. Nevertheless, I find her emphasis on the politicaleconomic framework of the discussion on unemployed foreign-born women interesting in the Swedish context as the rhetoric is so similar regarding the homogenisation, victimisation, and even criminalisation of unemployed migrant women.

What I find relevant and original about Farris's contributions is that her theoretical scope moves beyond the focus on migrant women as a vulnerable group of workers to understand what category of workers they are made to be. Her contribution also moves beyond the focus on governance, which has dominated much of the analysis of migrant unemployment within the field of critical migration studies, towards an analysis that explores what forms of labour supply are created through these classifications. Thus, Farris creates a productive point of departure for exploring what form of labour supply migrant women represent in contemporary capitalism and how policies, regulations, discourses, and laws produce and reinforce this labour supply. In this article, I use Farris's theoretical frame to explore a specific labour market reform to analyse the specific role of ES and how the figuration of the foreign-born woman creates a specific form of labour supply. While I do not have the ambition of fulfilling her analysis, as my study is qualitative in nature, I want to carefully try to read my empirical material in a way that is inspired by Farris's theoretical framework. As migration and labour policies are becoming more entangled (Sager \& Öberg, 2017), we need to pay more and closer attention to how labour market policies are used not only to legitimise unequal access to social rights and higher levels of exploitation but also to create new categories of workers.

\subsection{Methodological Framework: 'Our Researcher'}

Inspired by the tradition of institutional ethnography (Smith, 2006), in 2018, for over three months I have conducted fieldwork in diverse municipality projects targeting foreign-born migrant women. The study is part of a research project financed by Riksbankens Jubileumsfond (RJ), which particularly aims to frame the dialogue between academia and societal actors. Thus, the research project needs to be supported not only by the researcher's academic institution but also by the institution where the research project is to take place-in my study, the municipality of Malmö. Another important aspect of the research programme's framework is that the researcher is expected to move between the academy and the institution supporting the project; in my case, the municipality of Malmö became my workplace. While I had earlier experience of doing fieldwork in workplaces, my research position was often that of a generously accepted outsider; in this study, those who-to a certain extent-are my research subjects, the employees at the municipality, speak of and relate to me as their 'own researcher'. While I do not conceptualise my 'being there' as a natural access point to the truth regarding societal relations, I strongly believe that the focus on participant observation within feminist institutional ethnography (Campbell, 2004) enables a closer look at the practice of everyday life. Thus, the research design combines a prolonged stay in the field (three months) with a focus on following the action-doing in-depth interviews with both professionals and unemployed women. In this article, however, the focus will be on interviews with three professional workers within the municipality. The material in this article is from the first workshop held in the municipality aimed to create policies for the specific 
group of foreign-born women (however, as will be discussed, this was challenged by the participants) and is, therefore, a good point of departure to explore how governmental policies are implemented and challenged.

The main material in this article, however, consists of governmental and municipal policies and media texts presented in relation to debates on foreign-born women and the introduction of ES. I have chosen this material in an attempt to grasp how foreign-born unemployed women are represented and how this representation is embedded in the creation of ES.

Labour studies scholar Robert Pereira (2014) argues that critical occupational research should engage in the use of the 'what's the problem' (WPR) approach in order to expand 'research into politics, policies, and systems of governance and how they influence everyday occupation, participation, and inclusion of individuals, communities, and populations' (Pereira, 2014, p. 399). According to feminist political scientist Carol Bacchi (2009), a 'what's the problem represented to be?' approach to policy is a method for exposing the meaning involved in policy. A central argument by Bacchi is that governments and, one could argue, municipalities (in dialogue with or in contradiction to governments and private actors), do not 'address' problems but that they identify, name, and shape problems in specific ways that are embedded in and mirror societal power relations. In her own words:

How the 'problem' is represented or constituted, matters...because the way in which the 'problem' is represented carries all sorts of implications for how the issue is thought about and for how the people involved are treated and are evoked to think about themselves. (Bacchi, 2009, p. 1)

To grasp how migrant women are represented, we need to explore how 'the problem' with migrant women is defined within the unemployment debate as the definition of 'the problem' shapes the labour and gender politics developed to confront it. While both Bacchi and Pereira stress the need to analyse documents, one of the first challenges of my research was the lack of written material at the level of the local municipality on the topic. While the 'unemployed foreign-born woman' was created as a national problem, there was a lack of documentation defining what the problem really was. Paradoxically, there is well-established public discourse on foreign-born women and underemployment that is rather coherent and similar regardless of political sympathies.

In this article, I have therefore mainly used governmental material when talking of the unemployed foreignborn woman and the introduction of ES in relation to this group to explore how the problem is represented on a national political level and has influenced the ways in which local municipalities need to work. In the first section of the analysis, the tension between the local and the state political debate is explored and how local actors try to translate the national problem to a local level. In the following section, the analysis focuses on the central meaning that is embedded within the figuration of the unemployed foreign-born woman.

\subsection{The Workshop: Creating Consent}

The government's focus on foreign-born women has had direct implications for the municipality where I conducted my research. The managers of the Labour Department gave one of the municipality employees the assignment to 'do something in relation to foreignborn women' (personal communication, March 5, 2018). What she was asked to do was rather vague, but it was clear that the municipality needed to signal that they take the 'problem' seriously. She continues:

As there were no documents or analyses of what they thought the problem was for foreign-born women, I asked what the focus should be, what do you think is the problem? You need to know what the problem is if you want to find a solution. (Personal communication, March 5, 2018)

The employee was critical of the term foreign-born women because she found it 'discriminatory' as, in her own words, 'it placed the focus on migration and not on other issues'. She, therefore, invited key actors in the non-profit sector to a workshop with the title 'Vulnerable Women in the Labour Market' instead of a workshop called 'Unemployed Foreign-born Women'. In the translation from the national to the local level, there was a reinterpretation of the problem, which challenged the figuration of the unemployed foreign-born women.

The invitation to the workshop described the event as offering inspiration 'to reflect on how the municipality and the non-profit sector can co-operate in supporting vulnerable women in the labour market' (invitation folder). Over 50 people participated in the workshop, 40 from non-profit organisations and 10 from the municipality's Labour Department. I was initially asked, in my role as a researcher, to give an introduction describing the position of migrant women in the labour market, but as so many people attended the meeting, they decided that the focus should be on the discussion.

We were divided into groups around tables with large sheets of paper with Post-It notes on them. We were told to draw a big tree on the paper. On the roots, we wrote 'causes', on the tree trunk we wrote 'problem' and on the tree crown we wrote 'effects'. After a presentation, our first assignment was to discuss who was included in the category 'vulnerable women in the labour market'. The groups defined as vulnerable by the workshop participants were numerous and included women living in social and economic vulnerability, older women, single mothers, women with poor education, women with parttime employment, women addicted to drugs and criminalised in different ways, and foreign-born women. It 
seemed that the municipal employee responsible for the workshop had managed to move beyond the focus on foreign-born women and through the term 'vulnerable women' made visible the fact that many women today share a precarious situation in the labour market.

The second task for the workshop participants was to identify the causes of unemployment, and here, suddenly, something happened. What was identified as structural and institutional causes of vulnerability for single mothers or barriers for women working part-time with small children were not present when foreign-born women (who are often single mothers) were discussed.

The vulnerability of foreign-born women was explained by their culture and traditions and the patriarchal power of their men. And, contrary to all of the other groups, it was stressed that their unemployment status, because it was caused by 'cultural differences', could be passed on from generation to generation. Therefore, it was argued that creating jobs for foreign-born women was not only important for the women, but also for their children. Some participants made serious efforts to challenge the prevailing discourse. In particular, two young women with migrant backgrounds tried to question this division. One of them argued that migrant women did not need to be depressed because they were out of paid work. I later interviewed her:

When they said that one inherits one's mother's unemployment, that made me angry. My mother has always worked at home, and look at me-l am working. She was the best role model, and she has always pushed me to study. (Personal communication, May 2, 2018)

The other woman, who I also interviewed after the workshop stressed the problem of not discussing the structural causes of unemployment. Working in a woman's shelter, she often met women, she explained, whose main problem was that they could not find a room of their own:

Structural homelessness - that is what I would like to discuss. The problem is that many women do not have a place to live and if you don't have that it is impossible to have a job. And if you do not have a job, you cannot pay your rent, and even if you have a paid job, during a couple of hours they take your social security directly, and then you cannot even afford to work a little. The system is inflexible while, at the same time, as they always say, that foreign-born women need to be flexible. (Personal communication, May 2, 2018)

There were no responses to the two women's reflections. In the end, despite the efforts of the municipal employee responsible for the workshop, two clear-cut categories of women emerged: women whose labour market problems evolved from the gender-unequal society and labour market and foreign-born women whose vul- nerable position in the labour market was explained by their traditional/patriarchal culture. The latter group's unemployment was defined as a problem for them and their children. While the interpretations surfacing from the workshop, to some extent, were similar to those produced by the national government and broadly published in national and social media in the previous few months when debating the 'problem of unemployed migrant women', it is important to stress that initially there was a more complex picture emerging that linked the situation of different precarious groups of women to one another.

However, this complexity is difficult to uphold as the municipality is given special funds to target foreignborn women, already defining them as a special problem group. In the next section, I will discuss the central components embedded within the figuration of the foreignborn woman.

\subsection{The Woman Far Away}

One of the central arguments often repeated in the workshop was that migrant women, in the words of one of the participants, 'come from cultures where women do not work'. Can there really be countries where women do not work? If we are to believe the Swedish political socialdemocratic leadership on foreign-born women, the answer is yes. In the words of the Labour Market Minister, Ylva Johansson, foreign-born women have higher unemployment rates. 'It is also about cultural difference since it takes time for many of them to adapt to our genderequal society where both men and women work' (Karlsson, 2017).

While cheap migrant female labour in the last few decades has been the solution to the crisis of social reproduction in the Global North (Farris, 2017), and cheap migrant female labour has been at the core of the success of the Swedish model (de los Reyes, 2001), migrant women are still represented not only as women who have never worked but also as migrating from countries where women do not work. These countries are defined as being 'far away' from Sweden, both culturally and socially. In the application to the ESF, targeting foreignborn women, the municipality writes:

Sweden has a higher amount of foreign-born outside of the EU28. A high share comes from underdeveloped countries, which linguistically and culturally are far from Sweden. The foreign-born women to a higher degree come from countries where women do not work to such a vast extent. (Malmö Stad, 2016, author's translation)

In her analysis of parenting courses in Holland, Van den Berg (2016) analyses how space and time are central concepts in the 'legitimation of policy interventions into citizens' private lives'. Foreign-born citizens, she argues, are depicted as 'lagging behind', using a metaphor to move 
women to the centre via parenting courses. Van den Berg reflects on the aspect of activity, stating that 'raising five children without professional guidance, for example, is not "active", while volunteering in the neighbourhood is' (Van den Berg, 2016, p. 22). The author argues, then, that space-time is central as a strategic move in the processes of 'othering'. To be far away is also something, as Van den Berger argues, that is linked to time. Announcing an investment of 135 million SEK to 'facilitate the access to paid work for foreign-born women', the Minister of Finance Magdalena Andersson declared:

The big difference between foreign and domesticborn women in the labour market is not acceptable. There are still women in Sweden that are waiting to make the journey that so many others did in the 50s, 60s, and 70s, a journey towards freedom and autonomy. (Government Press Release, 2017b, author's translation)

In relation to the labour market, I would argue that by referring to foreign-born women as lagging behind in time and space, labour market activation is depicted as a means of moving towards the future, towards democracy and gender equality. The idea of paid work as a means of achieving gender equality has been central to Swedish labour movements and part of feminist movements (Carbin, Overud, \& Kvist, 2017). The higher rate of unemployment for foreign-born women is, therefore, defined not only as a problem for them but for the nation at large:

If foreign-born women would participate in the labour market in the same manner as domesticborn women, the GDP level is expected to be $1.5 \%$ higher, unemployment levels $1 \%$ lower and public finances would be strengthened by approximately 37 billion SEK. (Government Press Release, 2017b, author's translation)

Migrant women are not only represented as a threat to reaching gender equality but also as a financial problem and an economic burden. As the figuration of the foreignborn woman is that of one in need of labour market salvation in order to be free and equal, labour market activities are portrayed as charity work. Some of the municipal employees whom I talk to use terms such as 'helping them', 'breaking their isolation', and 'giving them hope', leaving the impression that the municipality is rescuing foreign-born women from their oppressive culture and their patriarchal men.

The idea of salvation, I would argue, is an important part of the creation of what Farris labels a regular army of reproductive labour as it legitimises the creation of a group of employees for which labour market participation is depicted as a feminist act of liberation, and opposing these activities is evidence that one is 'far away' and gender oppressed. The idea that the municipality and the whole Swedish nation is helping foreign-born women in order for them to gain power and autonomy also places higher institutional demands on them to participate in these integration/labour market projects.

\subsection{From Victims to Villains}

Minister of Labour Ylva Johansson, commenting on the investment of 141 SEK for the establishment of foreign-born women declared: 'The former government introduced the right to paid work for the newly arrived; we have added the obligation to participate' (Svensen, 2018). Researchers have argued that foreignborn women within the unemployment complex are often depicted as victims (McGlinn, 2018; Vesterberg, 2015). According to Farris, this is a central aspect of what creates a convergence around femonationalism. I would argue that we are witnessing a trend towards a representation as victims of their cultures but also as villains in relation to the Swedish welfare state. The unemployed foreign-born women are portrayed as women who exploit the parental and social security system and therefore are in need of obligations, rules, and clear-cut demands. When it comes to migrant women, the demands are often articulated as concerns for their gender equality, their children's wellbeing and the nation's gender equality, hence the removal of social rights is often described as a feminist measure. Among the measures implemented, especially targeting migrant woman, is the restriction of parental benefits and the demand that one continues with SFI, even when one is home with small children. Minister of Labour and Establishment Ylva Johansson declared that social assistance can become a 'trap', and therefore, for instance, demands on education are introduced in order to get social assistance 'that will clarify the individual's responsibility for the knowledge needed to get into work' (Social Democratic Party, 2018a) as well as a restriction on the right to parental leave for parents who come to Sweden with children for better establishment of foreign-born women in the labour market (Social Democratic Party, 2018a).

In a debate published just before the Social Democratic Party's congress, Prime Minister Stefan Löfven and Finance Minister Magdalena Andersson wrote an article with the headline 'Newly Arrived Women Cannot Be Locked in Their Homes'. A central argument was that the high levels of unemployment among foreign-born women 'are unacceptable in a gender-equal county'. Gender equality is defined as something that exists in Sweden. One of the proposals from the government was that the 'social orientation course' for the newly arrived should focus less on practical issues and more on issues of Swedish norms and Swedish values, for instance, 'gender equality between men and woman and freedom of speech' (Olsson, 2018). Foreign-born women are represented as victims of patriarchal cultures but at the same time as exploiting the gender-equal system, for instance, by taking too much parental leave. Therefore, some in- 
vestments are made to restrict migrant women's possibilities of utilising the benefits that the feminist movement has gained, such as day-care and parental leave, as it is implied that migrant women are trapped by them. In defence of the proposed reduction of parental leave for migrant parents, the Minister of Social Security declared: "For our part, it is primarily an important gender equality reform. It's about shortening the time for foreign-born women to enter the labour market" (Aftonbladet, 2017).

What is defined as a feminist victory, the right to parental leave, when it comes to unemployed migrant women is suddenly defined as an obstacle to their fulfilment of being gender equal.

The higher demands placed on migrant women are also legitimised as something that will 'rescue' the women's children. Ylva Johansson stresses that it is important for the foreign-born woman to work so she can 'influence and be a good role model for her children' (Karlsson, 2017). The notion that it is negative for foreignborn women's self-confidence and wellbeing to be isolated in their homes has been a central argument for the restriction of parental leave for migrant parents. Social rights such as parental leave that were created to increase gender equality are suddenly described as 'gender traps' when these rights are acted upon for foreignborn women; to abolish or restore them is considered an intervention of a 'feminist' government. As discussed earlier, the entanglement of labour market policy and social policy has become stronger as the municipalities are the ones implementing demands that restrict social assistance in different ways. For instance, the government presented the demand that people who want access to social assistance must participate in SFI: "If you speak bad Swedish, than it's an obstacle to getting a job. I think it's reasonable to ask you to learn by going to SFI" (Holmqvist, 2018).

Nikolas Rose and Peter Miller's book Governing the Present: Administering Economic, Social and Personal Life (2008) and their concept of advanced liberalism have been central in analyses of how governments and municipalities understand and govern the unemployed. A central argument is that unemployment during this era is not defined as a social problem but as an individual problem. The individual problem can be solved if the unemployed participate in different activities and, in the case of migrants, in becoming 'Swedish' (Vesterberg, 2015). The authors argue that one effect of the processes in transforming unemployment from a social to an individual problem is a fragmentation of the unemployed, where different groups are addressed and targeted in different ways, creating, on one hand, new professions with specific knowledge about 'groups' and at the same time making it more difficult for groups to create solidarity bonds between them. For instance, in separating the migrant woman from the domestic-born woman, many of the issues defined as gender issues, such as lower salaries, unequal distribution of time and wealth, and unequal access to representation and influence, disappear from the municipality agenda in relation to migrant women.

The entanglement between a gendered cultural racism, emphasising the need of salvation for migrant women through employment, and an individualistic approach placing the causes of unemployment on the individual (and their culture) gives room for the definition of a problem, the foreign-born woman, who can bring those extra hands to the public sector.

\subsection{Bringing that Extra Smile}

I usually arrive at my current workplace, in the municipality of Malmö, at 8:30 am. In the coffee room, there is already coffee in the thermos. The dishwasher that was full yesterday is now empty, as is the sink that, yesterday, was filled with cups. In the corridor, I am, by the permanent professional municipal staff, told that I should not put away dishes from the washing machine or make my own coffee in the morning because those are 'their jobs', and 'we should not take the jobs from them if we want to help them'. All these employees whom we should 'allow' to work (as if their labour was not necessary compared to the labour of the municipality staff) are dressed in black shirts with the inscription 'NORA'. There are around 40 of these people, employed as cleaners, restaurant workers, and janitors. Most of the NORA workers are migrants suffering racialisation, and many of them are migrant women. The workers, who clean, move furniture, carry things, make coffee and so forth, are all employed under the reform measure of ES, a labour market reform aimed at decreasing the levels of unemployment, especially among newly arrived migrants and people who have been unemployed for a period of more than two years. The municipality's goal is for over 5000 people to be employed through ES. Today, the municipality employs in total 22,000 people.

ES has been described as a reform that not only helps the unemployed into the labour market but also gives workplaces a 'silver lining':

Extra Services means meaningful task assignments for the individual with salaries according to collective agreements. Extra Services helps to improve quality in, for example, health care, school, and elderly care by making it possible to perform tasks that would otherwise not be performed. At the same time, an unemployed person gets the opportunity to move into the labour market. (Social Democratic Party, 2018b, author's translation)

Malmö is one of the cities where unemployment levels are high and therefore one of the cities where ES is seen as an important 'way' into the labour market. Most of the ES employees are working within the municipality (day-care, schools, elder care). While many of the labour market activities I participated in focused on learning the Swedish language and developing 'social skills', the gov- 
ernment and the municipality of Malmö have made important financial investments in the creation of ES. In Malmö, migrant women occupy half of the $1,000 \mathrm{ES}$ positions. The focus of the ES employee is to do things in the workplace outside the scope of regular employee tasks.

We know that many co-workers in schools, in care have a difficulty in fulfilling their tasks within the planned time. By supporting them, more elderly people get a chance to go for a walk in the sun, and teachers can get help with administration and in creating peace and quiet in our schools. (Government Press Release, 2017a, author's translation)

In the information provided by the Labour Department, it is argued that 'through Extra Services municipalities, county councils and non-profit actors in the welfare area are provided the opportunity to get an extra resource that can support the core activity of the institution' (Department of Labour, 2017). This is the framework through which Finance Minister Magdalena Andersson reads the creation of ES: 'We want to continue to guarantee the quality in the welfare system, without it leading to extensive raises in municipal taxes' (Persson, 2017). Therefore, the new ES will be used to make working conditions for permanent workers better without employing new workers with formal salaries and full labour rights. After years of cutbacks and New Public Management transformations (Selberg, 2012), the exit of white Swedish women from the care professions has been identified by both academic and public debate regarding the municipality's difficulties in recruiting new groups of workers. The Prime Minister and Minister of Finance have declared a special investment towards 'unemployed foreign-born woman' and argue that ES is an important investment:

There is also a need for easier access to the labour market, especially for those with little or no educational background who are a bit older. Therefore, Extra Services in the public sector must be established. They strengthen well-being and serve as an entrance into the labour market, especially for foreign-born women. It may be an extra adult in the classroom, at break or at lunch, which relieves teachers with tasks that need to be done but are not always included. There may be more employees in retirement homes that have that extra time for conversation or for a walk, which increases the well-being among the elderly. (Andersson \& Löfven, 2017)

In contrast to Farris's ideas, foreign women are not to be employed as care workers, but as workers that enable the regular workforce to continue to function despite cutbacks and the neoliberal management of professional care work in the public sector. People in ES are not only precariously positioned but also have a total lack of autonomy and a total dependency on their employers.
Furthermore, as they are not offered education during these years and cannot include the years as practice, they are not academically trained to obtain professional care work positions in the future.

This frame provides the municipalities with cheap and often state-subsidised labour while at the same time creating paid work for many Swedish-born (white) women responsible for 'activating' foreign-born women and creating better working conditions for Swedish-born (white) women within the public sector. Farris stresses that ideas regarding gender equality are central to legitimising labour market activities. However, the centrality of this idea does not seem to be getting women directly into paid care work; instead, in Sweden, it seems to be creating a non-professional labour force that can bring that little extra to public organisations in neoliberal crisis.

Contrary to many other neoliberal-inspired reforms of labour market activities, ES provides employment with stable salaries and work tasks that are socially needed, so in many ways this reform provides workers with higher levels of security and well-being than, for instance, FAS 3 , where people were forced to work without financial remuneration and often in jobs that were not experienced as meaningful. However, still, with ES, (migrant) workers are not given opportunities for career paths that would open for stable employment within the public sector, running the risk of creating a specific fraction of service workers, especially as they are not given the possibility of education in their field of work even though demands on formal education in the public sector are high. The paradox is that while high investments are made in the reform of ES, there is an enormous need for workforce in the public sector.

\section{Conclusions}

The figure of the unemployed migrant woman is at the core of labour market policies at the level of the municipality. Scholarship on these policies, particularly how they are operationalised in diverse labour integration projects', has shown that they often tend to reproduce colonial and racist discourses on migrant women, create jobs for municipality-employed white Swedish women, and are seldom successful regarding employment possibilities for migrants suffering racialisation. Central to my argument is that, contrary to what is asserted by the social-democratic leadership, these policies not only do not open paths towards stable employment but create a specific gender and racialised labour force that ameliorates the tensions created by the introduction of new public management in publicly financed organisations such as health and education.

My study sheds light on how these discourses are reproduced, despite the efforts of the municipal employees themselves to challenge them, and, more specifically, how they are operationalised through the ES labour policies that aim to integrate migrant women into the labour market and are also understood as measures promoting 
gender equality. The study identifies a shift in the discourse, where, while migrant women continue to be represented as victims in public discourse and social policies, they are also represented as being lazy and unwilling to work, qualities that legitimate the need for more repressive interventions towards the group. I have shown how these processes of inclusion and also of serious repression are not conflicting with one another; on the contrary, combined, they legitimate relevant cuts in social and labour rights in the name of the progress of Swedish gender equality. The focus on the employment of migrant women in private care, which has often dominated gender research, needs to be complemented by an analysis of how state and municipality practices are creating a service class within the public sector, whose aim is to 'serve' both workers and citizens in a public sector highly slimed by austerity politics and New Public Management.

With regards to the workshop at the municipality, for a couple of hours, with a focus on the vulnerable woman, rather than on the 'foreign-born woman', the contours of a shared experience of exploitation in an unequal labour market (and an unequal responsibility of the reproductive work) took shape. In many ways, this challenged the femonationalist assumption that migrant women are in need of special demands, and on the contrary, showed that woman share experiences that could be more actively used to create unemployment policies.

\section{Acknowledgements}

I am grateful to RJ and Malmö Stad for their economical support.

\section{Conflict of Interests}

The author declares no conflict of interests.

\section{References}

Abiala, K. (2000). Säljande samspel: En sociologisk studie av privat servicearbete [Selling interaction: A sociological study of private service work]. Stockholm University, Stockholm, Sweden.

Aftonbladet. (2017, March 16). Begränsad föräldrapeng för invandrare [Restricted parental benefit for immigrants]. Retrieved from https://www.aftonbladet. se/nyheter/a/0aOwG/begransad-foraldrapeng-forinvandrare

Andersson, M., \& Löfven, S. (2017). Nyanlända kvinnor får inte fastan i hemmet [Newly arrived woman should not be allowed to get stuck at home]. Retrieved from https://www.aftonbladet.se/debatt/ a/j5aXb/nyanlanda-kvinnor-far-inte-fastna-i-hemmet

Anthias, F., Kontos, M., \& Morokvasic-Müller, M. (2013). Paradoxes of integration: Female migrants in Europe. Dordrecht: Springer Netherlands.

Arbetsförmedlingen. (2018). Extratjänster [Extra Ser- vices]. Retrieved from https://www.arbetsformed lingen.se/download/18.1cd5631315084841e7e24ca 6/1525249708591/extratjanst-ag-faktablad.pdf

Ardalan, P. (2016). Women making herstory: Women making history: 100 år av immigrantkvinnors liv och arbete i Malmö [Women making herstory: Women making history. 100 years of migrant woman's life and work]. Malmö: Malmö Stad.

Bacchi, C. (2009). Analysing policy. What's the problem represented to be? Australia: Pearson Education.

Barker, V. (2017). Nordic nationalism and penal order: Walling the welfare state. Milton: Routledge.

Behtoui, A. (2017). 'Främlingen' bland svensk 'Homo Academicus' [The 'Alien' among Swedish 'Homo Academicus']. Sociologisk forskning, 54(1), 91-110.

Campbell, L. (2004). Mapping social relations: An introduction to institutional ethnography. Toronto: Altamira Press.

Carbin, M. A., Overud, J. A., \& Kvist, E. A. (2017). Feminism som lönearbete: Om den svenska arbetslinjen och kvinnors frigörelse [Feminism as paid labour. On the Swedish working line and women's liberation]. Stockholm: Leopard förlag.

Dahlstedt , P., \& Lalander, P. (2018). Manifest: För ett socialt arbete i tiden [Manifest: For a social work for its time]. Lund: Stundentlitteratur.

de los Reyes, P. (2001). Mångfald och differentiering: diskurs, olikhet och normbildning inom svensk forskning och samhällsdebatt [Diversity and differentiation: Discourse, inequality and normative education in Swedish research and public debate]. Solna: SALTSA.

de los Reyes, P. (2014). Delegationen för jämställdhet $i$ arbetslivet, 2014. Inte bara jämställdhet: intersektionella perspektiv på hinder och möjligheter i arbetslivet [Delegation for the Gender Equality in Working Life, 2014. Not just gender equality: Intersectional perspectives on obstacles and opportunities in working life]. Stockholm: Fritze.

Department of Labour. (2017). Extratjänster-En hundraprocenting möjlighet [Extra Service-One hundred percent Opportunity]. Retrieved from http:// www.regeringen.se/49ba4f/contentassets/257eff7b9 5ef42508f075aaafeb943fb/faktablad-om-extratjanst. pdf

Farris, S. (2017). In the name of women's rights: The rise of femonationalism. Durham and London: Duke University Press.

Gavanas, A. (2010). Who cleans the welfare state? Migration, informalization, social exclusion and domestic services in Stockholm. Stockholm: Institute for Futures Studies.

Government Press Release. (2017a). 500 miljoner till kommuner och landsting som särskilt bidrar till att minska arbets/ösheten [500 million to municipalities and county councils to reduce unemployment]. Retrieved from https://www.regeringen.se/press meddelanden/2017/06/500-miljoner-till-kommuner -och-landsting-som-sarskilt-bidrar-till-att-minska-ar 
betslosheten

Government Press Release. (2017b). Regeringen vill att fler utrikes födda kvinnor ska komma i arbete [The government wants more foreign-born women to get into work]. Retrieved from http://www.regeringen. se/pressmeddelanden/2017/09/regeringen-vill-attfler-utrikes-fodda-kvinnor-ska-komma-i-arbete

Government Press Release. (2018). Uppdrag att förbättra nätverk och kontakter på arbetsmarknaden för utrikes födda kvinnor [Mission to improve the networks and contacts in the labor market for foreign born women]. Retrieved from https://www. regeringen.se/4948a5/contentassets/5902ae60335a 4aa99db41ce2c0f7b266/n18-01430.pdf

Giritli Nygren, K., \& Schmauch, U. (2012). Picturing inclusive places in segregated spaces: A participatory photo project conducted by migrant women in Sweden. Gender, Place \& Culture: A Journal of Feminist Geography, 19(5), 600-614. doi:10.1080/ 0966369X.2011

Gubrium, E., \& Fernandes, G. (2014). Policing Norwegian welfare: Disciplining and differentiating within the bottom rungs. Social Inclusion, 2(3), 5-17.

Holmqvist, A. (2018, March 14). S lovar hårdare språkkrav på bidragstagare [S promises tougher language requirements for economic security recipients]. Retrieved from https://www.aftonbladet.se/ nyheter/samhalle/a/vmzJM4/s-lovar-hardare-sprak krav-pa-bidragstagare

Karlsson (2017, November 29). Vi har inte gjort saker tillräckligt bra' [We have not done things well enough]. Retrieved from https://www.aftonbladet.se/nyheter/ samhalle/a/8wwevw/ylva-johansson-vi-har-inte-gjort -saker-tillrackligt-bra

Larsson, J. (2015). The market of integration and labour: How gender equality, labour and other 'Swedish' phenomena are constructed by employment service officials and private actors (Doctoral dissertation). Linköping University, Linköping, Sweden.

Lill, L. (2007). Att göra etnicitet: inom äldreomsorgen [Doing ethnicity: Within elderly care] (Doctoral dissertation). Malmö högskola, Malmö, Sweden.

Lowe, L. (2015). The intimacies of four continents. Durham: Duke University Press.

Malmö Stad. (2016). ESF Application. Diarienummer. 2016/00465

Martinsson, L., Griffin, G., \& Giritli Nygren, K. (Eds.) (2016). Challenging the myth of gender equality in Sweden. Bristol: Policy Press.

McGlinn, M. (2018). Translating neoliberalism: The European Social Fund and the governing of unemployment and social exclusion in Malmö, Sweden. (Doctoral dissertation). Malmö University, Malmö, Sweden.

Miller, P., \& Rose, N.S. (2008). Governing the present: Administering economic, social and personal life. Cambridge: Polity.

Mohanty, C. T. (2003). Feminism without borders: Decol- onizing theory, practicing solidarity. Durham: Duke University Press.

Mulinari, P. (2007). Maktens fantasier \& servicearbetets praktik : Arbetsvillkor inom hotell- och restaurangbranschen i Malmö [The fantasises of power and service practices: Working conditions for hotel and restaurant workers in Malmö]. Linköping: Tema Genus, Institutionen för Tema, Linköpings universitet.

Mulinari, P. (2017). Racism as intimacy-Looking, questioning and touching in the service encounter. Social Identities: Journal of the Study of Race, Nation, and Culture, 23(5), 600-613.

Mulinari, P. (2018). To care and protect: Care workers confronting Sweden democrats in their workplace. NORA: Nordic Journal of Feminist and Gender Research, 26(2), 84-98. doi:10.1080/08038740. 2018.1449766

Olsson, L. (2018). Nyanlända ska lära sig svenska värderingar [Newly arrived shall learn Swedish values]. Retrieved from https://sverigesradio.se/sida/ artikel. aspx ?programid $=83$ \&artikel $=6841123$

Paulsen, R. (2015). Vi bara lyder: En berättelse om Arbetsförmedlingen [We only obey orders: A story about the Employment Service]. Stockholm: Atlas.

Pereira, R. (2014). Using critical policy analysis in occupational science research: Exploring Bacchi's methodology. Journal of Occupational Science, 21(4), 389-402. doi:10.1080/14427591.2013.806207

Persson, M. (2017). Välfärdslöftet 20 mijarder till kommunerna [Welfare promises 20 million to the municipalities]. Aktuellt $i$ Politiken. Retrieved from https://aip.nu/2017/07/05/valfardsloftet-20miljarder-extra-till-kommunerna

Povrzanović Frykman, M., \& Öhlander, M. (2018). Högutbildade migranter $i$ Sverige [Highly educated migrants]. Lund: Arkivförlag.

Sager, M., \& Öberg, K. (2017). Articulations of deportability. Changing migration policies in Sweden 2015/2016. Refugee Review, 3(1), 2-14.

Selberg, R. (2012). Femininity at work: Gender, labour, and changing relations of power in a Swedish hospital. (Doctoral dissertation). Växjö: Linnéuniversitetet, Lund).

Smith, D. E. (2006). Institutional ethnography as practice. Lanham, MD: Rowman \& Littlefield.

Social Democratic Party. (2018a). Faster integration. Everyone that can work should work-regardless of how you are. Retrieved from https://www.social demokraterna.se/engagera-dig/integration

Social Democratic Party. (2018b). Extratjänster [Extra Services]. Retrieved from https://www.social demokraterna.se/var-politik/a-till-o/extratjanster

Svensen, L. (2018). Spring budget. The Government invests in foreign born woman. Dagens Arena. Retrieved from http://www.dagensarena.se/innehall/ varbudgeten-regeringen-satsar-pa-utrikesfodda-kvin nor 
van den Berg, M. (2016). 'Activating' those that 'lag behind': Space-time politics in Dutch parenting training for migrants. Patterns of Prejudice, 50(1), 21-37. doi/full/10.1080/0031322X.2015.1128622

Vesterberg, V. (2015). Learning to be Swedish: Governing migrants in labor-market projects. Studies in Continuing Education, 37(3), 302-316. doi:10.1080/ 0158037X.2015.1043987

Vesterberg, V., \& Dahlstedt, M. (2018). Portrait of author- ity: A critical interrogation of the ideology of job and career coaching. Pedagogy, Culture \& Society, 13(4), 1-15. doi:10.1080/14681366.2018.1450284

Vikman, U., \& Westerberg, A. (2017). Arbetar kommuner på samma sätt? Om kommunal variation inom arbetsmarknadspolitiken [Do municipalities work in the same way? About municipal variation in labor market policy]. Stockholm. Institutet för arbetsmarknad och utbilnindgspolitisk utvärdering.

\section{About the Author}

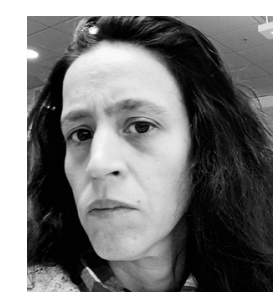

Paula Mulinari works as a Lecturer and Researcher at the Institution of Social Work, at Malmö University. Her research has mainly been concerned with issues of labour market inequalities, especially in service and emotional work, and workplace resistance. Her last article explores the struggles against austerity and racist politics within the public sector. 